\title{
PROTOTIPE ALAT KIRIM PESAN SINGKAT TINDAK KEJAHATAN SEBAGAI SOLUSI PENINGKATAN KEAMANAN BERBASIS LOKASI
}

\author{
Wire Bagye ${ }^{1}$, Maulana Ashari ${ }^{2}$, Mohammad Taufan Asri Zaen ${ }^{3}$ \\ ${ }^{1}$ Program Studi Teknik Informatika, STMIK Lombok \\ ${ }^{2,3}$ Program Studi Sistem Informasi, STMIK Lombok \\ Jalan Basuki Rahmat No.105 Praya Lombok Tengah (83511) \\ Email : ${ }^{1}$ wirestmik@gmail.com, ${ }^{2}$ aarydarkmaul@gmail.com, \\ 3opanzain@gmail.com
}

\begin{abstract}
ABSTRAK
Sangat jarang tindak kejahatan dapat dilakukan pertolongan dini atau ditangani pihak keamanan saat pelaku masih berada ditempat kejadian perkara (TKP). Sangat minim korban kejahatan dapat melakukan pengiriman pesan disebabkan korban dalam intimidasi pelaku, handphone menjadi barang rampasan, dan kondisi psikis korban. Melaporkan ke kepolisian membutuhkan waktu yang relatif lama yaitu antara 30 menit sampai 2 jam. Untuk menurunkan angka tindak kriminal dan upaya pertolongan dini maka dikembangkan alat kirim pesan singkat tindak kejahatan. Pengembangan alat mengimplementasikan mikrokontroller Arduino Uno R3 sebagai komponen utama untuk penyimpanan program dan koordinat lokasi diperoleh dari modul GPS Ubox 160n. pesan singkat berisi biodata dan koordinat lokasi akan dikirim oleh modul GSM SIM800L. Nomor tujuan akan menerima pesan yang dapat digunakan untuk penelusuran lokasi kejahatan melalui Googlemaps. Alat ini di desain portable dengan deskripsi fungsi bagian pada boks serta dilengkapi Baterai yang dapat diisi ulang dengan pengisi baterai handphone, praktis dan efisien. Dengan menggunakan alat kirim pesan singkat tindak kejahatan berbasis lokasi ini sangat efisien waktu. Pengiriman pesan tindak kejahatan dilakukan dengan waktu sangat singkat yaitu dengan menekan tombol merah pada alat. Dengan melakukan tap pada pesan secara langsung aplikasi Googlemaps terbuka dan menampilkan lokasi tindak kejahatan. Panduan menuju lokasi menggunakan fasilitas “Directions” pada Googlemaps.
\end{abstract}

Kata Kunci: Prototype, Arduino Uno, Pesan Singkat, Googlemaps.

\begin{abstract}
Very rarely the crime can be done early help or handled by the security forces while the perpetrators are still at the scene of the crime. The effort to get help from crime by reporting to the police requires a relatively long time, which is between 30 minutes to 2 hours. To reduce the number of criminal acts and early relief efforts, a tool to send short messages of crime was developed. Development of tools implements the Arduino Uno R3 microcontroller as the main component for program storage. Location coordinates are obtained from the Ubox 160n GPS module. Short messages containing biodata and location coordinates will be sent by the GSM SIM900L module. The destination number will receive a message that can be used to trace the location of the crime through Googlemaps. This tool equipped with a battery that can be recharged with a cell phone charger making this tool portable, practical and efficient. Using this Alat kirim pesan singkat tindak kejahahatan is very time efficient. The sending of a crime message is done in a very short time. By tapping the message directly the Googlemaps application opens and displays the location of the crime.
\end{abstract}

Keywords: Prototype, Arduino Uno, Short Message, Googlemaps

Author Korespondensi (Wire Bagye)

Email : wirestmik@gmail.com

\section{PENDAHULUAN}

Penelitian ini bertujuan implementasi Internet of Things (IoT) untuk menghasilkan sebuah alat kirim pesan singkat tindak kejahatan sebagai penelusuran lokasi. Alat dikembangkan dengan Mikrokntroller Arduino dan modul pendukung Global
Positioning System (GPS) dan Global system for Mobile Communications (GSM). Dilakukan pengujian kinerja alat pada dua puluh (20) titik rawan terjadi kejahatan untuk menguji kemampuan alat dalam mengirim pesan serta rentan watu saat pesn dikirim sampai pesan diterima pada handphone 
tujuan. Pengembangan alat ini sebagai upaya mengurangi waktu pengiriman informasi ke pihak kepolisian membutuhkan waktu yang relatif lama yaitu antara 30 menit sampai 2 jam.

Telepon selular saat ini telah menjadi barang yang selalu dibawa saat bepergian[1]. Pada penelitian dilakukan optimasi penggunaan fitur aplikasi peta yang dapat digunakan sebagai penelusuran lokasi sebuah tempat atau koordinatnya[2]. Pesan singkat yang dikirmkan oleh alat dapat mengarahkan telepon selular membuka aplikasi Googlemaps saat pesan di Tap. Menu directions pada Googlemaps sangat membantu dalam memandu pegguna telepon seluler menuju sebuah lokasi dengan tampilan grafis jalur menuju lokasi. Aplikasi Googlemaps telah dilengkapi dengan audio deskripsi petunjuk jalan yang akan dilalui.

Pengiriman informasi elektronik jarak jauh melalui implementasi mikrokontroller Arduino Uno sebagai pusat kendali dan tambahan modul dapat memberikan peningkatan kemanan dan waktu penyaluran informasi yang jauh lebih cepat dibandingkan dengan cara konvensional [3]. Salah satu teknik pengiriman informasi maupun sinyal perintah dengan biaya murah dan kebutuhan perangkat keras yang minim dengan memanfaatkan jalur komunikasi Global Sistem mobile yang memiliki jangkauan pengiriman sinyal seluruh daerah pada sebuah negara bahkan ke seluruh dunia dengan syarat provider layanan GSM telah memiliki stasiun Base Transceiver Station (BTS) pada daerah tersebut [4].

Untuk menunjang kinerja Arduino maka diperlukan shield. Shield adalah perangkat keras yang digabungkan dengan Arduino untuk memberikannya tujuan tertentu. Misalnya modul sensor sebagai masukkan dan atau keluaran bahkan fungsi dari Shield dapat menjadikan Arduino menjadi sesuatu yang kompleks seperti ponsel[5]. Shield dapat berupa modul sangat sederhana dan sangat kompleks. Shield dijual preassembled atau sebagai kit. Dengan kemasan dalam bentuk Kit memungkinkan lebih banyak pilihan penggunaan tergantung kebutuhan. Beberapa kit mengharuskan untuk memasang sebuah board. Shieldyang lebih kompleks hanya membutuhkan pin header. Berbagai jenis shield antra lain modul WiFi, modul GPS, modul GSM, modul LCD, modul Camera, modul card Reader. Shield dapat ditumpuk untuk menggabungkan fungsi yang berbeda. Shield harus menggunakan pin yang sama pada Arduino. Shield harus menghubungkan dengan pin 0 volt yang betulis GND agar dapat berkomunikasi dengan Arduino[5].

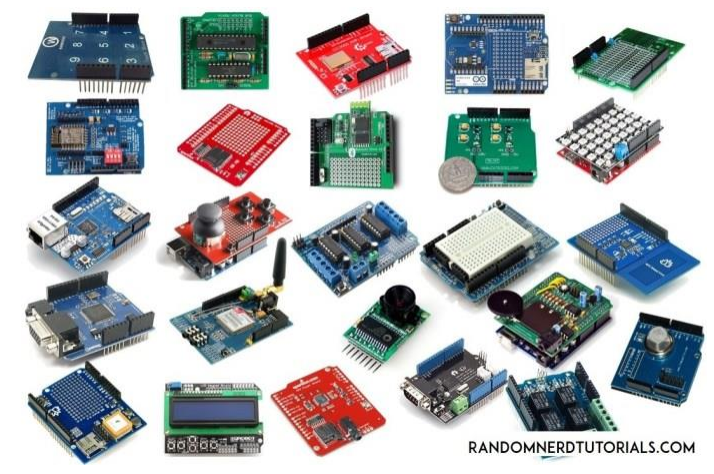

Gambar 1. Berbagai Jenis Shield [6]

\subsection{Arduino R3}

Modul mikrokontroller Arduino terbaru hingga saat ini adalah Arduino Uno R3 (dirilis pada 2011). Dapat dikatakan bahwa ini merupakan vanila polos board Arduino[5]. Board versi R3 ini cuhup handal yang baik dan dapat diandalkan yang cocok untuk berbagai proyek. Arduino Uno dalam bahasa Italia berarti nomor satu, dinamai untuk rilis versi 1.0 dari perangkat lunak Arduino. Para pendahulu ini memiliki berbagai nama, seperti Serial, NG, Diecimila (10.000 dalam bahasa Italia, untuk menandai bahwa 10.000 papan telah terjual) dan Duemilanove dan 2009 menunjukkan tahu produksinya. Board Arduino Uno telah mengantar dalam beberapa urutan yang sangat dibutuhkan untuk penamaan board. Kata R3 berkaitan dengan revisi fitur revisi yang ke tiga (3)[5].

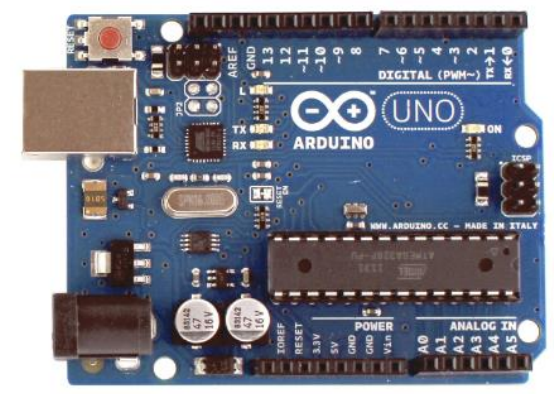

Gambar 2. Arduino Uno R3[5]

Pemrograman Arduino menggunakan 
aplikasi Arduino IDE. Aduino IDE dilegkapi dengan bagian listing program untuk menulis listing program ynag akan dijalankan, layanan feirfy untuk menguji listing program, serta fasilitas upload untuk mengisi file program dalam ekstensi.hex (Dot Hek. Kedalam ard Arduino Uno. Fitur pendukung lain juga tersedia sebagai penunjang penggunaan aplikasi Arduino IDE.

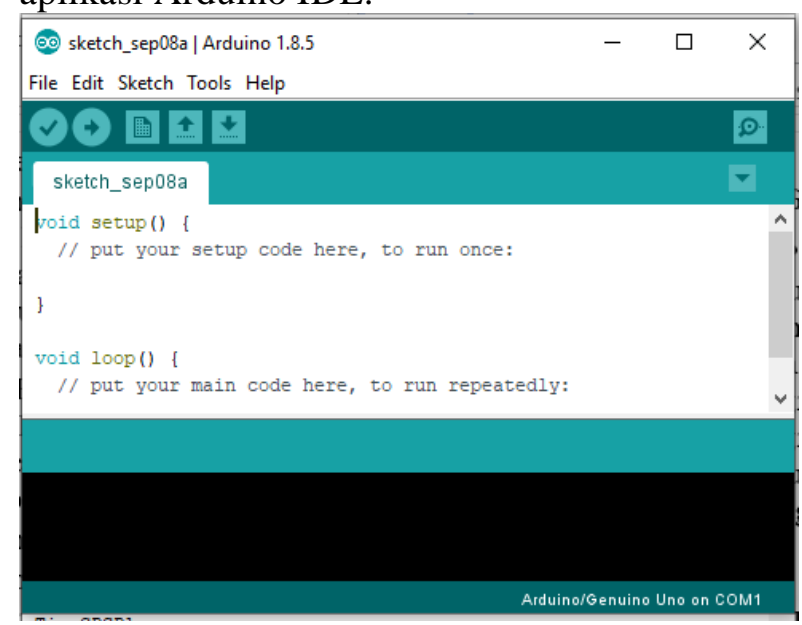

Gambar 3.Tampilan Apikasi Arduino IDE Versi 1.8.5.

\subsection{Base Transceiver Station (BTS)}

BTS perangkat jaringan yang berfungsi menyalurkan sinyal informasi telepon seluler. Sebuah BTS dapat dimiliki oleh satu atau lebih penyedia layanan. Jaringan dimaksud dapat berupa layanan GSM, CDMA, WiFi, WAN dan lainya. Pada telepon selular menggunakan layanan teknologi komunikasi GSM dan CDMA. Sebutan lain dari layanan tersebut ialah RBS (RadioBase Station), node B (3G Network), BS (base station) [7]. BTS beroperasi pada frekuensi $900 \mathrm{MHz}$ dengan panjang gelombang $30 \mathrm{~cm}$. Kualitas sinyal ditentukan oleh rentan jarak antar dua buah menara BTS dan penghalang. Biasanya BTS terpasang beberapa perangkat transceiver (TRXs) sehingga dapat melakukan transmisi bebera frekuensi yang berbeda dan berbagai sektor sel Sebuah BTS dikendalikan oleh sebuah kontroler utama base station dengan fungsi base station kontrol (BSC). BSC ini dilaksanakan sebagai unit diskrit atau dapat juga tergabung dalam TRX di BTS kompak. sejumlah BSC menyediakan operasi dan pemeliharaan (Operational and Maintenance) koneksi dengan menggunakan Network Monitoring System (NMS), dan mengelola kondisi operasi dari setiap transceiver (TRX), serta penanganan perangkat lunak dan koleksi alarm. Struktur dasar dan fungsi dari BTS tetap sama tanpa teknologi nirkabel [7].

\subsection{Modul GPS}

Untuk mendapatkan lokasi koordinat diperlukan sebuah modul GPS (Global Positioning System). Pada modul GPS Shield sudah terpasang tetapi membutuhkan solder untuk memasang pin header atau soket header dari modul GPS terhubung ke Arduino. Data dari modul GPS dapat diatur ke UART untuk secara langsung mengirim data lokasi ke pin RX dan TX perangkat keras Arduino, 0 dan 1, atau diatur ke DLINE untuk mengirim data ke pin digital 2 dan 3 (default). Kode dapat dikirim ke Arduino hanya ketika diatur ke DLINE[5].

Modul GPS Logger Shield memungkinkan melacak dan menyimpan informasi lokasi menggunakan Global Positioning System. Koordinat dapat disimpan sebagai file .txt yang kemudian dapat di-overlay ke Googlemaps atau divisualisasikan dengan cara lain Pin RX dan TX harus terhubung ke dua pin digital, seperti 2 dan 3. Anda dapat mengaktifkan fungsi opsional lainnya, seperti LED signaling untuk menunjukkan ketika data dicatat, pin untuk memantau pulsa dari jam sinkronisasi GPS, dan pin untuk mendeteksi ketika kartu SD ada di dalam slot. Untuk memudahkan dalam pemrograman maka digunakan library pada listing program[5].

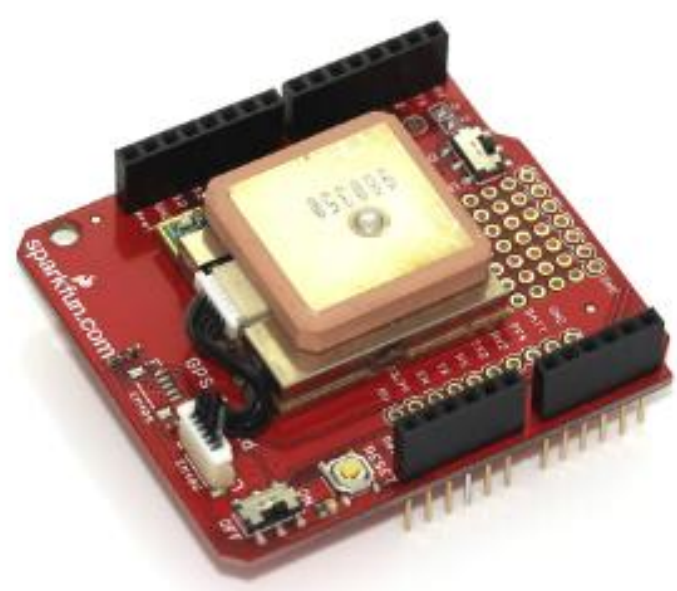

Gambar 3. GPS Logger Shield Kit v1.1[5]

\subsection{External Library}

Library merupakan sebuah kumpulan kode 
yang dapat mengeksekusi perintah-perintah tertentu berdasarkan fungsi dan prosedur yang terbangun oleh file headernya[8]. Library memudahkan programmer dalam menyusun listing program dengan menggunakan fungsi yang telah dikembangkan pada sebuah library. Aplkasi Arduino menyediakan sejumlah library standar bawaan yang memudahkan untuk melakukan pemrograman pada Arduino. Disebut external library karena kode yang akan dieksekusi berada diluar listing program utama.

Library disediakan terutama untuk memenuhi fungsi dari shield atau modul penunjang untuk input output perangkat. Sebuah library terdiri dari dua file yaitu ekstensi .h (dot h) untuk header dan .cpp (dot CPP). File .h sebagai inisialilisasi port dan file .cpp merupakan listing program yang akan dijalankan. Untuk menjalakan library maka kedua ekstensi file tersebut disimpan dalam folder libraries path C:IProgram Files\Arduinollibraries. Berbagai library yang siap digunakan dapa di unduh pada situs https://github.com. Dengan menggunakan library maka akan menghemat jumlah listing program dan memudahkan pencarian kesalahan pada saat pemrograman. Gambar 4 merupakan contoh folder LED13 berisi library pemrograman LED yang berisi h (dot $h$ ) untuk header dan .cpp (dot CPP). File .h.

\begin{tabular}{|c|c|c|}
\hline (1) GDBStub & $3 / 30 / 20166: 44 \mathrm{AM}$ & File folder \\
\hline D. GSM & 3/30/2016 6:01 AM & File folder \\
\hline (1) Hash & $3 / 30 / 20166: 44 \mathrm{AM}$ & File folder \\
\hline DI2Cdev & $5 / 1 / 20168: 12 \mathrm{AM}$ & File folder \\
\hline 13. Keyboard & 3/30/2016 6:01 AM & File folder \\
\hline Deypad & $8 / 24 / 2016$ 10:23 PM & File folder \\
\hline LED13 & 9/12/2016 9:35 PM & File folder \\
\hline 13. LiquidCrystal & 3/30/2016 6:01 AM & File folder \\
\hline Dil LiquidCrystal_I2C & $8 / 14 / 20163: 58 \mathrm{PM}$ & File folder \\
\hline Dis LMotorController & 7/28/2016 5:17 PM & File folder \\
\hline D. Mouse & $3 / 30 / 20166: 01 \mathrm{AM}$ & File folder \\
\hline 1]. MPU6050 & $8 / 7 / 201610: 22$ AM & File folder \\
\hline D. MPU6050_Arduino & 8/7/2016 10:55 AM & File folder \\
\hline Dis myservo & $4 / 23 / 20165: 46 \mathrm{AM}$ & File folder \\
\hline
\end{tabular}

Gambar 4. Folder LED13 pada Libraries Arduino[8]

\subsection{Metode R\&D}

Metode penelitian R \& D terdapat 10 tahapan yaitu: (1) Potensi dan masalah; (2) Pengumpulan data; (3) Desain produk; (4) Validasi desain; (5) Revisi desain; (6) Ujicoba produk; (7) Revisi produk; (8) Ujicoba pemakaian; (9) Revisi produk; dan (10) Produksi masal. Secara skematik langkah langkah tersebut dapat ditunjukkan seperti pada gambar berikut ini.

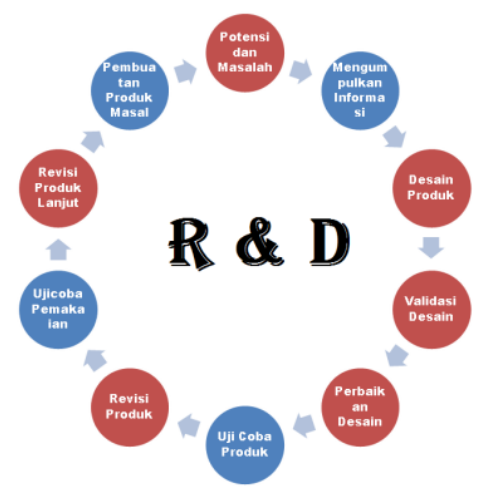

Gambar 5. Tahapan Metode Penelitian R\&D.

\section{METODOLOGI}

Tahapan pada penelitian dijabarkan pada gambar 5, yang terurai dalam sepuluh (10) kegiatan penelitian. Diagram alir penelitian digambarkan pada gambar 6 .

1. Potensi dan Masalah Identifikasi potensi masalah tindak kejahanan jalanan dilakukan dengan melakukan audiensi dan Focus Group Discussion (FGD) dengan pihak keamanan dalam hal ini pihak kepolisisan daerah NTB tentang masalah dan potensi penanganan Begal.

2. Mengumpulkan Informasi Mengumpulkan informasi dilakukan dengan Studi pustaka elektronik dan cetak terkait tentang model keamanan berbasis mikrokontroller dan IOT sebagai dasar desain alat.

3. Desain Produk Melalukn desain alat dengan komponen utama mikrokontroller arduino Uno dan modul pendukung serta desain kemasan. Pada tahap ini juga didesain flowchart kerja alat.

4. Validasi Desain Dilakukan presentasi dan FGD dengan pihak kepolisian Daerah NTB dan pakar ekektronik untuk validasi desain alat. Pihak kepolisian dalam hal ini terlibat sebagai tujuan pengeriman pesan SMS.

5. Perbaikan Desain Dilakukan perbaikan desain sistem dan fitur alat berdasarkan kelemahan dan masukkan dari pihak terkait.

6. Uji coba Produk Ujicoba pruduk dilakukan 
dengan melakukan implementasi desain yang telah di validasi. Dilakukan dengan merangkai Arduino Uno, Modul GSM, dan Modul GPS serta komponen penunjang Alat. Menulis kode program dan pengupload pada board Arduino Uno.

7. Revisi Produk Tahap ini dilakukan perbaikan produk berupa penambahan komponen atau sistem dari prototype untuk membrikan kinerja penyelesaian masalah.

8. Ujicoba Pemakaian Pengujian lapangan dilakukan di daerah daerah yang sering terjadi tindakan Begal. Dilakukan selama 4 hari pada daerah yang dapat dilalui kendaraan motor dan mobil.

9. Revisi Produk Revisi produk ini dilakukan jika daam ujicoba pemakaian masih terdapat masalah.

10.Pembuatan Produk Masal.

Pada penelitian ini tidak dilakukan produk masal namun dilakukan pembuatan Paten sederhana di Kementerian Hukum Dan Hak Asasi Manusia Republik Indonesia Direktorat Jenderal Kekayaan Intelektual (DJKI)

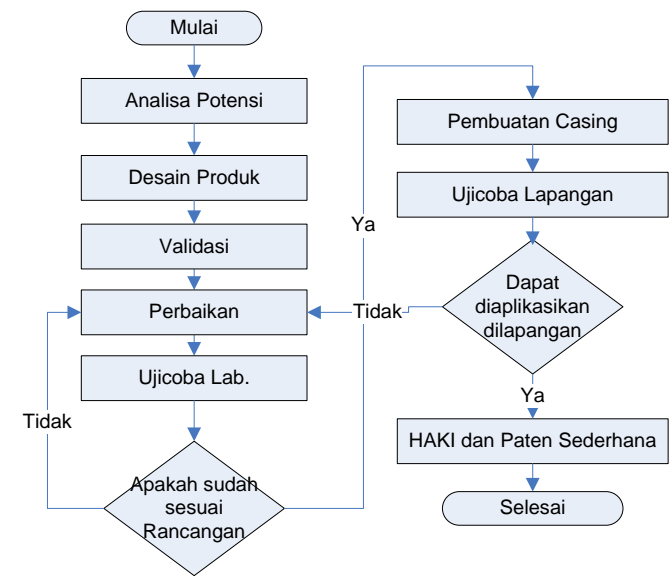

Gambar 6. Flowchart Penelitian.

\section{HASIL DAN PEMBAHASAN}

\subsection{Alur Kerja Sistem}

Alur kerja alat terlihat seperti gambar 7 menunjukkan cara kerja alat.

1. tindakan kejahatan jalanan

2. korban akan menekan tombol bahaya berwarna merah pada alat.

3. Alat kirim pesan kan membaca hasil tombol untuk mengambil koordinat lokasi selanjutnya mengirim pesan ke nomor tujuan dalam bentuk pesan singkat SMS (Short Message Service).

4. Dilakukan Tap pada pesan singkat maka aplikasi Goolemaps yang menampilan titik lokasi kejahatan

5. Secara grafis selanjutnya penelusuran lokasi memanfaatkan fasilitas Directions. Setelah menu Directions di pilih maka Googlemaps menampilkan panduan jalur menuju lokasi sampi dengan penelusuran sampai ke titik lokasi kejahatan.

6. Penggunaan Directions pada Googlemaps menuju lokasi kejahatan.

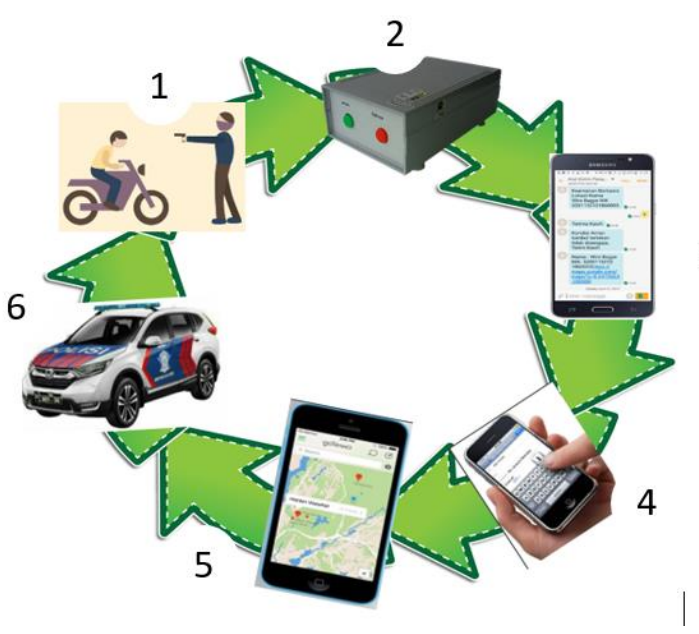

Gambar 7. Alur kerja alat.

\subsection{Alur Kerja Alat}

Alur kerja alat dimulai dengan mengidentifikasi kondisi tombol dan mengirim pesan. Jika tombol merah ditekan maka Arduino uno akan mengambil data koordinat dari modul GPS dan menggabung dengan pesan biodata pengguna yang selanjutyna dikirim ke nomor tujuan dalam bentuk pesan singkat. Jika tombol hijau ditekan maka alat akan mengirim pesan kondisi aman dan tombol ditekan dengan tidak sengaja. Jika nomor tujuan mengirim pesan singkat ke nomor alat denga isi pesan “?" sebagai permintan konfirmasi kondisi pengguna sehingga alat akan mengeluarkan bunnyi beep untuk memberikan informasi kepada pengguna alat bahwa alat telah mengirim pesan yang selanjutnya pengguna 
akan menekan tombol merah jika sedang terjadi bahaya dan tombol hijau jika aman.

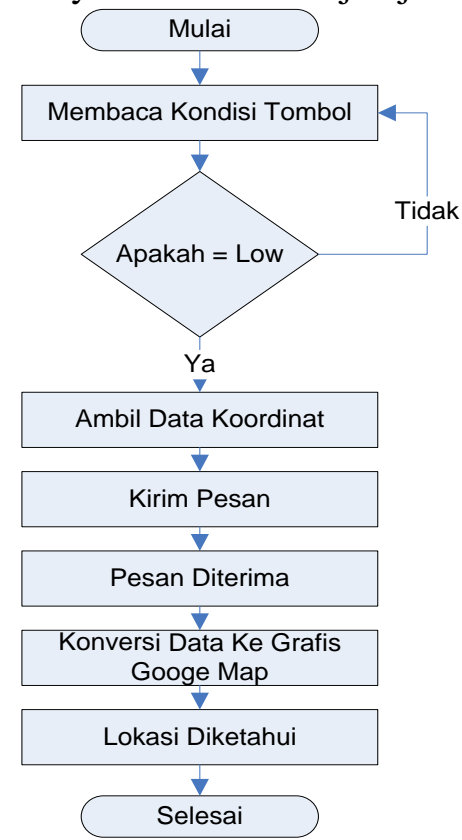

Gambar 8. Flowchart kerja alat

\subsection{Implementasi Hardware}

Implementasi hardware utama alat terdiri dari modul Arduino Uno R3, Modul GPS, dan Modul GSm Sim800i sedangkan hardware pendukung berupa Casing Boks ABS $150 \mathrm{X}$ 100 X $55 \mathrm{~mm}$ warna abu-abu, empat buah batrai dan satu modul pengisi btrai sekaligus converter 3.7volt DC menjadi 5 volt DC sebagai tegangan catu alat. Diagram hubungan jalur antar modul digambarkan pada gambar 8 .

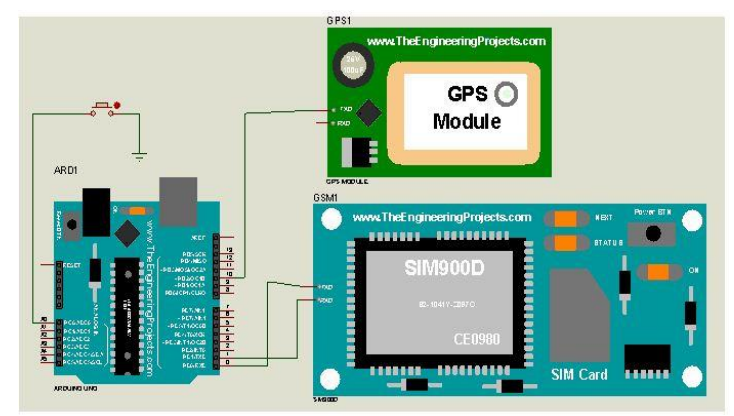

Gambar 9. Skema rangkaian antar modul

Prototype Alat Kirim Pesan Singkat Tindak Kejahatan Berbasis Lokasi yang terdiri dari: (1) Tombol saklar power, (2) Slot Kartu GSM, (3) Lampu Indikator, (4) Slot Mikro USB untuk pengisian baterai,(5) Tombol Hijau untuk kondisi aman, (6) Tombol Merah untuk kondisi bahaya, (7) Boks Plastik, (8) Baterai, (9) Rangkaian elektronika board Arduino Uno R3, pengisi batrai, Modul GSM, dan Modul GPS. Dikemas dengan Boks ABS 150 X 100 X 55 $\mathrm{mm}$ warna abu-abu, dua tombol hijau dan merah bagian depan, lampu indikator bagaian atas, slot pengisian baterai pada sisi kanan

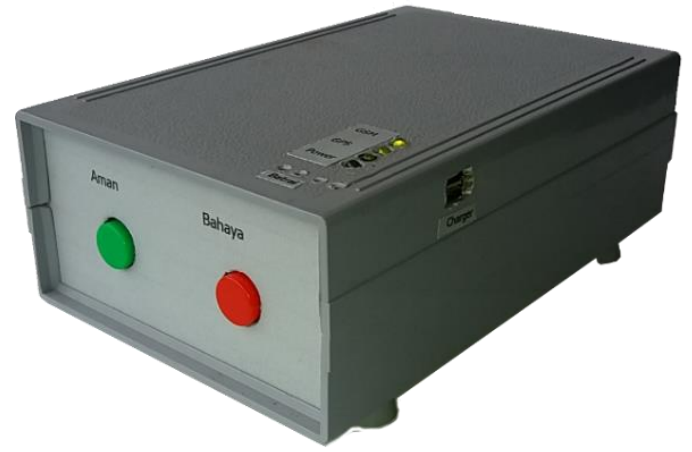

Gambar 10. Tampak perspektif Alat

Pada bagian belakang terdapat tombol saklar power untuk menghidup dan mematikan alat. slot USB untuk pemrograman ulang jika akan dilakukan perbaikan fungsi maupun perubahan nomor tujuan pengiriman pesan. Bagian bawa post USB terdapat selot kartu GSM sehingga memudahkan penguna dalam mengganti kartu.

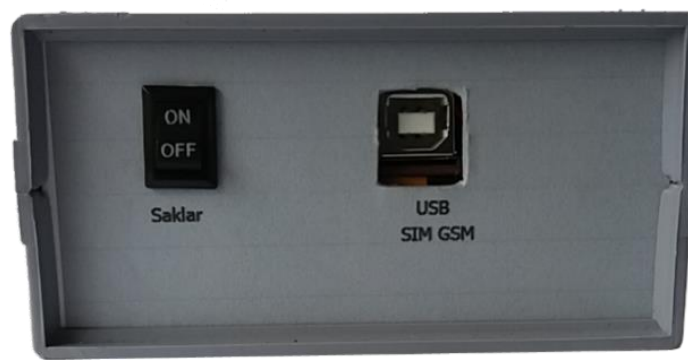

Gambar 11. Tampak belakang Alat

\subsection{Impelementasi perangkat lunak}

Implementasi perangkat lunak menggunakan beberapa library eksternal sebagai pendukung. Untuk koordinat modul GPS Ubox 160n menggunakan library Tiny GPS.h, untuk melakukan pengiriman pesan melalui modul GSM Sim800 digunakan library SIM900.h, Pstring.h, dan Library SMS.h yang merupakan library eksternal. 


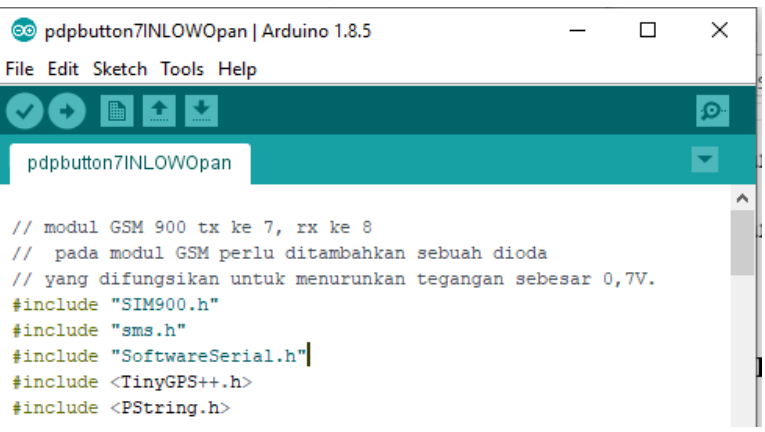

Gambar 12. Penggunaan Library Eksternal

Tahap selanjutnya dilakukan inisialisasi pin Arduino Uno untuk mementukan komunikasi Board Arduino dengan komponen pendukung. Inisialisasi pin yang digunakan pada alat kirim pesan singkat tindak kejahatan ditampilkan pada tabel 1.

Tabel 1. Inisialisasi Pin Arduino Uno

\begin{tabular}{|c|c|l|}
\hline No & Pin & Keterangan \\
\hline 1 & 3 & Led Indikator \\
\hline 2 & 11 & Buzzer beep \\
\hline 3 & 12 & Tomol aman warna hijau \\
\hline 4 & 13 & $\begin{array}{l}\text { Tombol bahaya warna } \\
\text { merah }\end{array}$ \\
\hline
\end{tabular}

Listing program untuk inisialisasi pin Arduino Uno ditampilkan pada gambar 13.

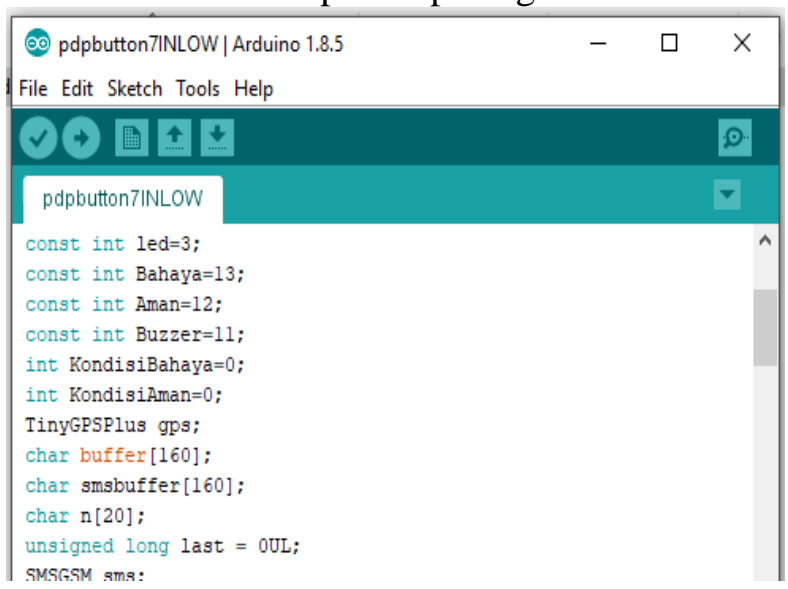

Gambar 13. Inisialisasi Pin Arduino Uno.

Pengisian nomor tujuan pengiriman SMS dengan penggunaan library SMS.h dengan mengisi nomor tujuan dan isi pesan. Pada percobaan digunakan nomor 08179256488 sebagai nomor tujuan dan isi pesan "Keamanan Berbasis Lokasi Nama Wire Bagye NIK 5201150101860003"
(0) pdpbutton7INLOWOpan | Arduino 1.8.5

File Edit Sketch Tools Help

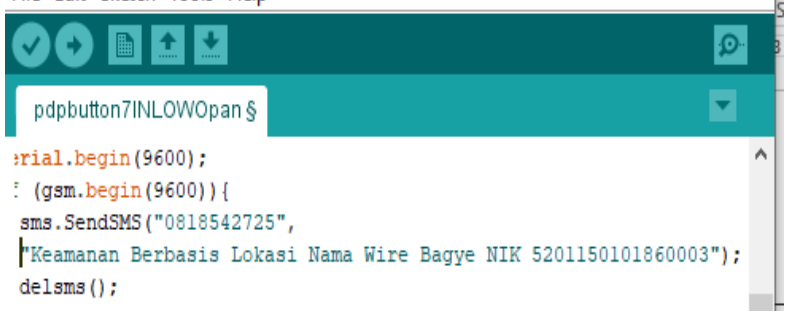

Gambar 14. Nomor tujuan pengiriman pesan

Selanjutnya penambahan enam (6) digit angka koordinat dari modul GPS pada bagian akhir pesan. Pada pesan juga ditambahkan link (tautan) https://maps.google.com/maps?q. link akan tergabung dengan titik koordinat pada pesan terkirim untuk menghasilkan satu link lokasi kejahatan. Gabungan link Googlemaps dan titik koordinat sebagai fungsi penelusuran lokasi dengan melakukan tap pada pesan masuk.

Fitur konfirmasi juga ditambahkan dalam prototype ini. Fitur ini sebagai konfirmasi kepada kedua belah pihak yaitu pengguna alat dan nomor tujuan pesan singkat. Hal ini bertujuan menghindari kesalahan lokasi tujuan penelusuran. Tabel 2 menunjukkan tambahan fitur alat.

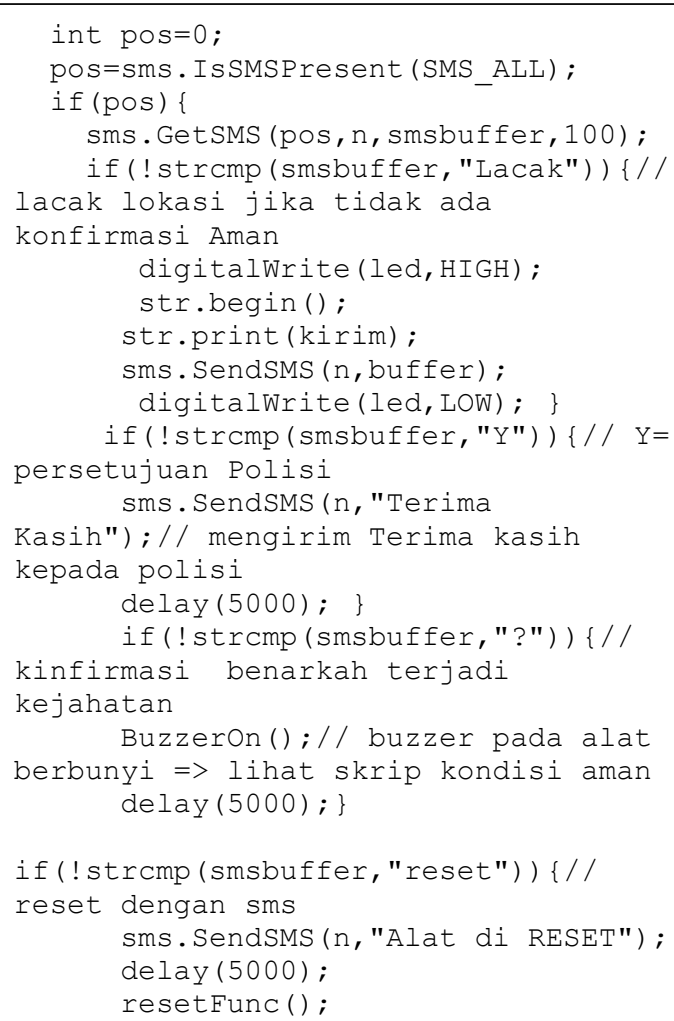


Gambar 16. Fitur konfirmasi

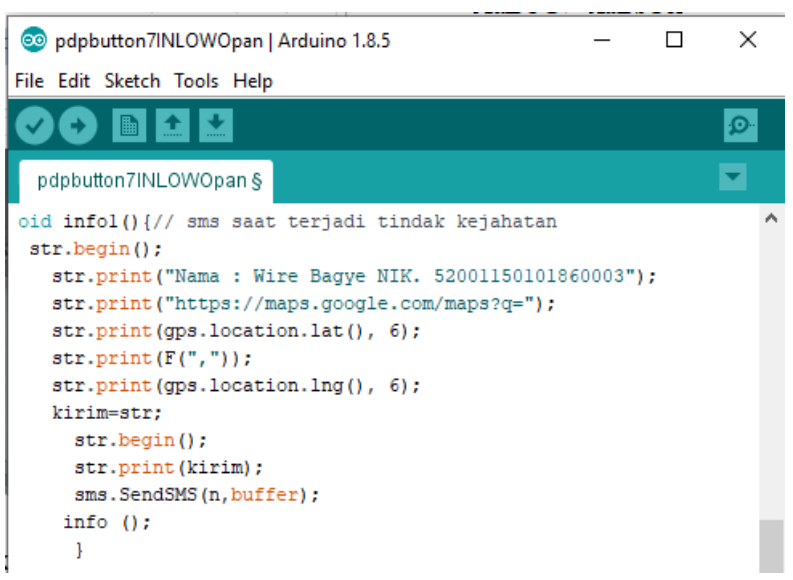

Gambar 15. Penggabungan koordinat pada link Googlemaps.

Tabel 2. Daftar Fitur Konfirmasi

\begin{tabular}{|c|l|lll|}
\hline No & Pesan & Keterangan & & \\
\hline 1 & Lacak & $\begin{array}{l}\text { lacak lokasi jika tidak ada } \\
\text { konfirmasi Aman }\end{array}$ & \\
\hline 2 & Y & persetujuan Polisi & \\
\hline 3 & $?$ & $\begin{array}{l}\text { Konfirmasi benarkah terjadi } \\
\text { kejahatan }\end{array}$ & \\
\hline 4 & Reset & Alat di RESET & & \\
\hline 5 & $\begin{array}{l}\text { Terima } \\
\text { kasih }\end{array}$ & $\begin{array}{l}\text { Mengirim Terima } \\
\text { polisi }\end{array}$ & kasih & kepada \\
\hline
\end{tabular}

\subsection{Pengujian Alat}

Pengujian dilakukan pada beberapa titik diwilayah kabupaten Lombok Tengah provinsi Nusa Tenggara Barat. Hal ini dilakukan untuk menguji respon alat pada beberapa daerah tertentu untuk mengukur waktu respon alat dan kinerja modul GPS.

Tabel 3. Tabel pengujian Alat

\begin{tabular}{|c|c|c|c|}
\hline No & Koordinat & Lokasi & Keterangan \\
\hline 1 & $\begin{array}{l}8^{\circ} 44^{\prime} 06.8^{\prime \prime S} \\
116^{\circ} 15^{\prime} 20.9^{\prime \prime} \mathrm{E}\end{array}$ & $\begin{array}{l}\text { Bendungan } \\
\text { Batujai }\end{array}$ & Berhasil \\
\hline 2 & $\begin{array}{l}8^{\circ} 44^{\prime} 48.0^{\prime \prime S} \\
116^{\circ} 15^{\prime} 03.6^{\prime \prime} \mathrm{E}\end{array}$ & $\begin{array}{l}\text { Mentokok } \\
\text { Baypass BIL }\end{array}$ & Berhasil \\
\hline 3 & $\begin{array}{l}8^{\circ} 37^{\prime} 08.0^{\prime \prime S} \\
116^{\circ} 11^{\prime} 42.4^{\prime \prime} \mathrm{E} \\
\end{array}$ & $\begin{array}{l}\text { Desa Bilebante, } \\
\text { Jonggat }\end{array}$ & Berhasil \\
\hline 4 & $\begin{array}{l}8^{\circ} 37^{\prime} 08.0^{\prime \prime S} \\
116^{\circ} 11^{\prime} 42.4^{\prime \prime} \mathrm{E}\end{array}$ & $\begin{array}{l}\text { Loang Tune, } \\
\text { Jonggat }\end{array}$ & Berhasil \\
\hline 5 & $\begin{array}{l}8^{\circ} 37^{\prime} 08.0^{\prime \prime S} \\
116^{\circ} 11^{\prime} 42.4^{\prime \prime E}\end{array}$ & $\begin{array}{l}\text { Pringgarata, } \\
\text { Jonggat }\end{array}$ & Berhasil \\
\hline 6 & $\begin{array}{l}8^{\circ} 39^{\prime} 40.2^{\prime \prime S} \\
116^{\circ} 12^{\prime} 40.9^{\prime \prime} \mathrm{E}\end{array}$ & $\begin{array}{l}\text { Jelantik, } \\
\text { Jonggat }\end{array}$ & Berhasil \\
\hline 7 & $\begin{array}{l}8^{\circ} 48^{\prime} 45.1^{\prime \prime S} \\
116^{\circ} 19^{\prime} 27.0^{\prime \prime} \mathrm{E}\end{array}$ & Tego, Pujut & Berhasil \\
\hline 8 & $\begin{array}{l}8^{\circ} 45^{\prime} 14.4^{\prime \prime S} \\
116^{\circ} 18^{\prime} 10.7^{\prime E} \\
\end{array}$ & Lajut, Pujut & Berhasil \\
\hline 9 & $8^{\circ} 48^{\prime} 42.8^{\prime \prime} \mathrm{S}$ & Pengembur, & Berhasil \\
\hline
\end{tabular}

\begin{tabular}{|c|c|c|c|}
\hline & $116^{\circ} 15^{\prime} 33.8^{\prime \prime} \mathrm{E}$ & Pujut & \\
\hline 10 & $\begin{array}{l}8^{\circ} 45^{\prime} 12.0^{\prime \prime} \mathrm{S} \\
116^{\circ} 20^{\prime} 24.3^{\prime \prime} \mathrm{E}\end{array}$ & sukaraja, Mujur & Berhasil \\
\hline 11 & $\begin{array}{l}8^{\circ} 45^{\prime} 53.7^{\prime \prime S} \\
116^{\circ} 21^{\prime} 50.4^{\prime \prime} \mathrm{E}\end{array}$ & $\begin{array}{l}\text { Mujur, Praya } \\
\text { timur }\end{array}$ & Berhasil \\
\hline 12 & $\begin{array}{l}8^{\circ} 45^{\prime} 59.9^{\prime \prime} \mathrm{S} \\
116^{\circ} 22^{\prime} 46.0^{\prime \prime} \mathrm{E}\end{array}$ & Sengkerang & Berhasil \\
\hline 13 & $\begin{array}{l}8^{\circ} 46^{\prime} 19.9^{\prime \prime S} \\
116^{\circ} 25^{\prime} 15.6^{\prime \prime} \mathrm{E}\end{array}$ & $\begin{array}{l}\text { Ganti, Praya } \\
\text { Timur }\end{array}$ & Berhasil \\
\hline 14 & $\begin{array}{l}8^{\circ} 45^{\prime} 03.3^{\prime \prime S} \\
116^{\circ} 24^{\prime} 00.3^{\prime \prime} \mathrm{E}\end{array}$ & Golong, Beleke & Berhasil \\
\hline 15 & $\begin{array}{l}8^{\circ} 47^{\prime} 03.9^{\prime \prime S} \\
116^{\circ} 23^{\prime} 26.4^{\prime \prime} \mathrm{E}\end{array}$ & $\begin{array}{l}\text { Semoyang, } \\
\text { Praya Timur }\end{array}$ & Berhasil \\
\hline 16 & $\begin{array}{l}8^{\circ} 48^{\prime} 07.2^{\prime \prime S} \\
116^{\circ} 23^{\prime} 31.7^{\prime \prime} \mathrm{E}\end{array}$ & $\begin{array}{l}\text { Embung Pare, } \\
\text { Praya Timur }\end{array}$ & Berhasil \\
\hline 17 & $\begin{array}{l}8^{\circ} 53^{\prime} 05.0^{\prime \prime S} \\
116^{\circ} 21^{\prime} 20.1^{\prime \prime} \mathrm{E}\end{array}$ & Mertak, Pujut & Berhasil \\
\hline 18 & $\begin{array}{l}8^{\circ} 53^{\prime} 22.9^{\prime \prime S} \\
116^{\circ} 17^{\prime} 13.3^{\prime \prime E}\end{array}$ & Kute, Pujut & Berhasil \\
\hline 19 & $\begin{array}{l}8^{\circ} 48^{\prime} 50.2^{\prime \prime S} \\
116^{\circ} 20^{\prime} 42.0^{\prime \prime} \mathrm{E}\end{array}$ & Teruwai, Pujut & Berhasil \\
\hline 20 & $\begin{array}{l}8^{\circ} 50^{\prime} 13.3^{\prime \prime S} \\
116^{\circ} 21^{\prime} 16.8^{\prime \prime} \mathrm{E}\end{array}$ & Bangket Parak & Berhasil \\
\hline 21 & $\begin{array}{l}8^{\circ} 49^{\prime} 48.3^{\prime \prime S} \\
116^{\circ} 22^{\prime} 34.4^{\prime \prime} \mathrm{E}\end{array}$ & $\begin{array}{l}\text { Kidang, Praya } \\
\text { Timur }\end{array}$ & Berhasil \\
\hline 22 & $\begin{array}{l}8^{\circ} 40^{\prime} 40.0^{\prime \prime S} \\
116^{\circ} 23^{\prime} 19.9^{\prime \prime} \mathrm{E}\end{array}$ & $\begin{array}{l}\text { Janapria, Praya } \\
\text { Timur }\end{array}$ & Berhasil \\
\hline 23 & $\begin{array}{l}8^{\circ} 40^{\prime} 49.1^{\prime \prime S} \\
116^{\circ} 22^{\prime} 36.0^{\prime \prime} \mathrm{E}\end{array}$ & $\begin{array}{l}\text { Pendem, Praya } \\
\text { timur }\end{array}$ & Berhasil \\
\hline 24 & $\begin{array}{l}8^{\circ} 39^{\prime} 20.7^{\prime \prime S} \\
116^{\circ} 18^{\prime} 37.7^{\prime \prime} \mathrm{E}\end{array}$ & $\begin{array}{l}\text { Montong Terep, } \\
\text { Praya }\end{array}$ & Berhasil \\
\hline 25 & $\begin{array}{l}8^{\circ} 39^{\prime} 14.6^{\prime \prime S} \\
116^{\circ} 17^{\prime} 06.8^{\prime \prime} \mathrm{E}\end{array}$ & $\begin{array}{l}\text { Aik Mual, } \\
\text { Praya }\end{array}$ & Berhasil \\
\hline 26 & $\begin{array}{l}8^{\circ} 39^{\prime} 49.0^{\prime \prime} \mathrm{S} \\
116^{\circ} 14^{\prime} 53.0^{\prime \prime} \mathrm{E}\end{array}$ & $\begin{array}{l}\text { Barejulat, } \\
\text { Jonggat }\end{array}$ & Berhasil \\
\hline 27 & $\begin{array}{l}8^{\circ} 40^{\prime} 53.0^{\prime \prime S} \\
116^{\circ} 13^{\prime} 10.9^{\prime \prime} \mathrm{E}\end{array}$ & $\begin{array}{l}\text { Nyerot, } \\
\text { Jjonggat }\end{array}$ & Berhasil \\
\hline 28 & $\begin{array}{l}8^{\circ} 43^{\prime} 09.7 " \mathrm{~S} \\
116^{\circ} 11^{\prime} 54.7^{\prime \prime} \mathrm{E}\end{array}$ & $\begin{array}{l}\text { Ungge, Praya } \\
\text { Barat }\end{array}$ & Berhasil \\
\hline 29 & $\begin{array}{l}8^{\circ} 40^{\prime} 48.2^{\prime \prime S} \\
116^{\circ} 11^{\prime} 13.0^{\prime \prime} \mathrm{E}\end{array}$ & $\begin{array}{l}\text { Labulie, } \\
\text { Jonggat }\end{array}$ & Berhasil \\
\hline 30 & $\begin{array}{l}8^{\circ} 53^{\prime} 26.5 " \mathrm{~S} \\
116^{\circ} 18^{\prime} 57.3^{\prime \prime} \mathrm{E} \\
\end{array}$ & Sukadana, Pujut & Berhasil \\
\hline
\end{tabular}

Pengujian penelusuran lokasi dilakuan dengan melakukan tap pada pesan masuk pada smartphone penerima. Selain pesan tindak kejahatan pengujian lain dilakukan pada fitur fitur tambahan alat. Pengujian dilakukan untuk memastikan kinerja alat telah sesuai rancangan. Secara berturut pada gambar 17 mendeskripsikan (1) penerimaan pesan dari Alat (2) Tampilan Setelah klik pada Pesan maka akan tampil Googlemaps, (3) Tampilan Seteah klik "Direction" (4) Tampilan Googlemaps panduan menuju lokasi tindak kejahatan. 

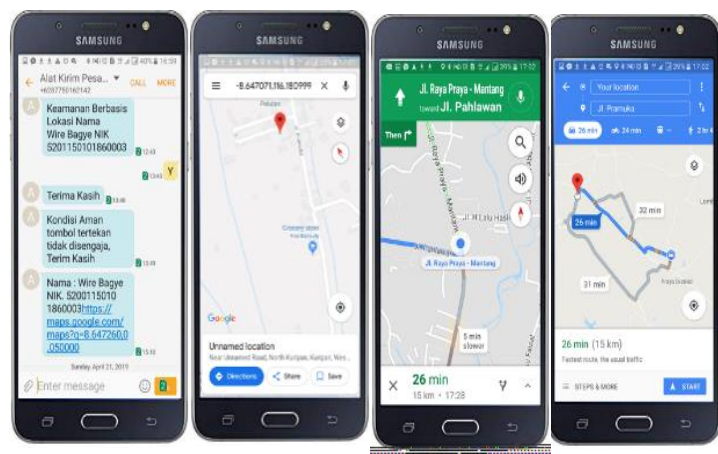

Gambar 17. Tampilan pesan singkat dan Googlemaps

\section{SIMPULAN DAN SARAN}

\subsection{Kesimpulan}

Penelitian telah menghasilkan prototipe alat kirim pesan singkat tindak kejahatan yang mampu mengirim pesan berisi biodata dan tautan Googlemaps yang dapat menjadi panduan pihak keamanan atau keluarga dalam penelusuran lokasi kejahatan. Hasil pengujian alat pada tigapuluh lokasi di Lombok tengah menunjukkan bahwa alat dapat melakukan pengiriman pesan SMS (Short Message Service). dengan waktu respon miminal 5 detik. Respon yang lambat bahkan alat tidak dapat mengirimkan pesan saat dioperasikan didalam ruangan disebabkan modul GPS gagal mendapatkan nilai koordinat.

\subsection{Saran}

Pada peneltian selanjutnya pada tema penelitian ini dapat dilakukan pengembangan antara lain:

1. Penambahan modul Keypad untuk pengisian nomor tujuan pengiriman pesan

2. Penambahan fitur perekaman koordinat lokasi tindak kejahatan untuk pemetaan pembaharuan daerah rawan kejahatan.

\section{UCAPAN TERIMA KASIH}

Ucapan terima kasih disampaikan kepada pihak pihak dan personal yang telah mendukung kegiatan penelitian ini antara lain:

1. Pihak Lembaga Penelitian Dan Pengabdian kepada Masyarakat STMIK Lombok.

2. Pihak kepolisian dalam hal ini polres Lombok Tengah NTB dalam partisipasi dalam Focus Group Disscussion (FGD).
3. Dosen dan karyawan STMIK Lombok dalam sumbangan pemikiran dan rujukan daerah ujicoba Alat.

4. Praktisi IoT Mataram yang telah memberikan masukkan revisi alat.

5. Data koelktor dan data analis

\section{REFERENSI}

[1] L. Wardhana and A. Purbawati, Teknologi Wireless Communication dan Wireless Broadband, 1st ed. Yogyakarta: Andi, 2010.

[2] H. Santoso, Implementasi Internet of Things Pada Jalur GPRS, 3rd ed. Situbondo: Elang Sakti, 2018.

[3] T. Bagye, Wire, Azizah, "Alat pengaman kandang berbasis mikrokontroler arduino uno," vol. 1, no. 2, pp. 62-67, 2018.

[4] W. Bagye, "Implementasi Jalur Komunikasi Global Sytem Mobile (GSM) Untuk Kontrol Robot Jarak Jauh Berbasis Mikrikontroller 2Atmel 89S52.," JIRE (Jurnal Informatika \& Rekayasa Elektronika., vol. 1, no. 1, pp. 1-6, 2018.

[5] J. Nussey, Arduino For Dummies, 1st ed. West Sussex: John Wiley \& Sons, Ltd, 2013.

[6] S. Santos, Rui. Santos, "25 Useful Arduino Shields That You Might Need to Get Random Nerd Tutorials," 2015. [Online]. Available: https://randomnerdtutorials.com/25arduino-shields. [Accessed: 09-Aug2019].

[7] I. M. S, "Pembuatan Alat Tracking Artefak pada Museum Menggunakan Modul GSM Berbasis Mikrokontroler dan Short Massage System .," vol. 03, no. 01, pp. 18-24, 2019.

[8] M. A. Ulinnuha, "Tutorial Membuat Library pada Arduino _ Blog Ulindev," http:///blog.ulindev.com, 2016. [Online]. Available:

http://blog.ulindev.com/tutorial-membuatlibrary-pada-arduino/. [Accessed: 09Aug-2019]. 